\title{
PEMBELAJARAN MENYIMAK DENGAN REKAMAN DIALOG INTERAKTIF UNTUK MELATIH KETERAMPILAN MENYIMAK SISWA
}

Oleh,

\author{
KALIS WARDOYO
}

kalizwardoyo@student.uns.ac.id

\section{Hakikat Keterampilan Berbahasa}

Manusia adalah makhluk yang senantiasa berkumpul dan bekerja sama dengan manusia yang lain, dalam melakukan kegiatan tersebut manusia memerlukan suatu alat untuk berkomunikasi yang disepakati bersama yakni bahasa, belum diketahui secara pasti kapan bahasa ditemukan tetapi dapat disimpulkan bahwa bahasa telah ada lama sekali sebelum manusia menemukan tulisan atau barangkali bahasa ada saat manusia diciptakan. Manusia dalam kehidupan selalu berinteraksi dan dalam interaksi tersebut terbentuklah hasil cipta, rasa maupun karsa berupa kebiasaan yang kemudian digunakan secara turun-temurun. Hasil dari cipta rasa dan karsa manusia adalah budaya sedangkan bahasa adalah produk atau bagian dari budaya manusia. Dari sinilah muncullah keterampilan berbahasa, Menurut Singer (Amung, 2000) keterampilan adalah derajat keberhasilan yang konsisten dalam mencapai suatu tujuan dengan efektif. Keterampilan sangat erat kaitannya dengan persona yang menggunakannya semakin sering seseorang berkomunikasi atau menggunakan keterampilan berbahasa yang ia miliki maka semakin terampil ia dalam menggunakan baik dalam bahasa tulisan. Apabila seseorang terampil maka orang tersebut akan memperoleh manfaat. Manfaat yang dapat diperoleh seseorang dalam kehidupan adalah keterampilan seseorang dapat meraih tujuan dengan mudah dan efektif. Keterampilan merupakan kemampuan untuk mengoperasikan pekerjaan secara mudah dan cermat (Widiastuti, 2010). Dapat dipahami bawa keterampilan adalah tingkat kemampuan seseorang dalam menjalankan sesuatu sehingga diperoleh tujuan secara mudah dan efektif.

Keterampilan bukan hanya dihubungkan dengan suatu hard skills seperti halnya keterampilan memasak, keterampilan berenang, dan sebagainya tetapi ada juga keterampilan bersifat soft skills seperti keterampilan berbahasa bahasa karena kemahiran berbahasa setiap orang berbeda-beda, perbedaan kemahiran ini dipengaruhi oleh berbagai faktor salah satunya pendidikan. Sebelum siswa belajar bahasa di sekolah, bahasa siswa telah dipengaruhi lingkungan di sekitarnya. Faktor lingkungan sangat mempengaruhi keterampilan bahasa siswa. 
Bahasa telah mengakar dalam kehidupan manusia terutama karena fungsinya yang dominan dalam komunikasi (Saddhono \& Rohmadi, 2014).

Bahasa adalah simbol baik berbentuk tulisan atau bunyi/lisan yang hanya dimiliki oleh manusia, simbol -simbol tersebut kemudian disepakati oleh para pengguna bahasa dan secara terus-menerus diturunkan dan digunakan secara turun-temurun. Menurut Kridalaksana (1983) bahasa adalah sistem labang bunyi yang arbiter yang arbiter yang digunakan oleh para anggota kelompok sosial untuk bekerja sama, berkomunikasi, dan mengidentifikasikan diri. Pendapat tersebut jelas menerangkan batasan bahasa sebagai alat atau sistem yang hanya dimiliki manusia sebagai pengguna bahasa untuk kegiatan bersosialisasi dengan kelompok, atau orang lain. Kedua pengertian tersebut di satukan antara keterampilan dan bahasa sesuai pendapat ahli bahasa yang mendefinisikan Keterampilan berbahasa sebagai keterampilan memilih lambanglambang, bunyi, tulisan guna menyampaikan pesan, dan si penerima harus terampil memberi makna terhadap lambang-lambang (bunyi/tulisan) yang berisi pesan yang disampaikan si pengirim pesan. (Mulyati, 2015). Dapat disimpulkan bahwa keterampilan berbahasa adalah suatu kemampuan yang dimiliki manusia dalam memilih dan memilah suatu lambang-lambang bahasa baik yang tertulis maupun yang diujarkan. Kemampuan tersebut tentunya dikusai secara baik dengan tata kebahasaan yang sudah disepakati para pengguna bahasa. Terampil berbahasa berati orang tersebut telah menguasai kemampuan bahasa baik secara aktif maupun pasif. Keterampilan aktif dalam berbahas berkaitan dengan keterampilan berbicara dan keterampilan menulis, sedangkan keterampilan pasif berkaitan dengan keterampilan menyimak dan keterampilan membaca.

\section{Ruang Lingkup Keterampilan Berbahasa}

Seperti yang diungkapkan di muka bahwa keterampilan berbahasa ada empat bentuknya yakni keterampilan berbicara, membaca, menulis, dam berbicara. Secara berurutan keterampilan yang pertama kali dikuasai adalah keterampilan menyimak yang sudah mulai dikuasai saat masih kecil di mana anak mengamati segala bentuk tingkah laku orang tua atau orang lain di sekitarnya, tak terkecuali bahasa yang diujarkan oleh lain, setelah menyimak barulah ia meniru ujaran tersebut sampai akhirnya ia bisa meniru dan menggunakannya untuk berbicara, baru setelah itu ia belajar membaca pada jenjang sekolah dasar dengan menguasai bahasa dalam bentuk bahasa tulis, dengan kemampuan itu barulah menguasai keterampilan yang terakhir yakni menulis. Bahasa sangat berkaitanerat dengan kehidupan sosial yang memebentuk logat atau aksen bahasa .Variasi bahasa berkenaan dengan penggunaannya, 
pemakaiannya, atau fungsinya ini disebut fungsiolek, ragam, atau register $\underline{\text { (Saddhono \& }}$ Wijana, 2018).

Lebih jauh ruang lingkup Keterampilan bahasa Indonesia mencakup komponen kemampuan berbahasa dan kemampuan bersastra yang meliputi aspek-aspek (1)menyimak yaitu kemampuan dalam menerima informasi secara jelas dan tepat; (2) berbicara yaitu mengajarkan berbagai macam kemampuan menggunakan bahasa lisan dalam berbagai peristiwa bahasa; (3) membaca yaitu mengajarkan kemampuan pemahaman dengan tepat dan cepat berbagai macam wacana, seperti narasi, persuasi, eksposisi, dan sebagainya; (4) menulis yaitu mengajarkan kemampuan membuat kalimat-kalimat yang baik, benar, dan sesuai, kemudian merakitnya menjadi paragraf dan berbagai macam wacana (Depdiknas, 2004).

Keterampilan tersebut tidak diterapkan secara sendiri-sendiri akan tetapi diintergrasikan ke dalam pembelajaran sehingga pembelajaran bukan hanya terisi oleh saru keterampilan saja. Dalam suatu keterampilan yang ditonjolkan atau dikonsentrasikan dalam pembelajaran keterampilan tertentu. Menurut Suparti (2007) dalam pembelajaran di kelas, keterampilan berbahasa tersebut diintegrasikan dalam satu kesatuan sebab keempat keterampilan tersebut sebenarnya meru-pakan catur-tunggal. Namun untuk kepentingan pembinaan keterampilan berbahasa siswa, masing-masing keterampilan berbahasa dapat dipilah sebagai fokus-fokus pembelajaran. Misalnya, untuk mengembangkan kemampuan menulis para siswa, pembelajaran dapat dikonsentrasikan pada pengembangan keterampilan menulis.

Dari beberapa keterampilan di atas menyimak menepati posisi yang sangat penting. Menyimak menjadi sarana dalam penguasaan bahasa sekaligus pemerolehan bahasa. Istilah penguasaan bahasa dan pemerolehan bahasa berbeda. Seperti yang terangkum dalam kamus Linguistik Umum bahwa pemerolehan digunakan dalam penguasaan bahasa pertama yang terjadi tanpa kesadaran untuk menguasai kaidah-kaidah bahasa itu secara alamiah tanpa diberi pelajaran khusus (Pandudinata, Sumarlam, dan Saddhono, 2018). Penguasaan bahasa lebih tertuju pada kegiatan pembelajaran di instansi formal seperti sekolah, atinya penguasaan bahasa bersifat sadar dan terencana. Lebih lanjut Sumarlam (2017) mengungkapkan istilah pembelajaran digunakan untuk penguasaan bahasa kedua yang dikuasai secara sadar,

\section{Keterampilan Menyimak}

Keterampilan menyimak pertama kali dikuasa sebelum keterampilan yang lain, tetapi sedikit sekali yang menaruh perhatian pada keterampilan ini karena dirasa semua orang pasti menguasai dengan baik, tetapi faktanya keterampilan yang bersifat pasif ini justru sangat mempengaruhi keterampilan berbicara di mana kualitas seseorang dapat dilihat dari cara 
berbicara. Padahal kemampuan berbicara seseorang yang bisa dikatakan mumpuni tidak akan tercapai tanpa seringnya orang tersebut menyimak bahan-bahan pembicaraan yang berkualitas seperti halnya pidato seorang tokoh hebat yang sering didengarkan seseorang akan mempengaruhi cara berbicara seseorang. Menyimak diibaratkan sebagai kegiatan menerima simbol bahasa yang diujarkan oleh seseorang sehingga mengetahui maksud atau makna yang hendak disampaikan oleh teman bicara. Menyimak, menurut Musfiroh (2004: 5), merupakan kegiatan mendengarkan bunyi bahasa secara sungguh-sungguh, saksama.

Menyimak merupakan upaya memahami ujaran yang dimaksudkan oleh pembicara. Dalam kegiatan ini melibatkan seluruh aspek mental kejiwaan seperti mengidentifikasi, menginterpretasi, dan mereaksinya. Selain itu, Tarigan (2008: 31), menyatakan bahwa menyimak adalah suatu proses kegiatan mendengarkan lambang-lambang lisan dengan penuh perhatian, pemahaman, apresiasi, serta interpretasi. Tujuannya untuk memperoleh informasi, menangkap isi atau pesan, serta memahami makna komunikasi yang telah disampaikan oleh sang pembicara melalui ujaran atau bahasa lisan. Dari sini dapat disimpulkan bahwa menyimak adalah keterampilan tidak bisa disamakan dengan mendengar karena menyimak itu lebih bersifat intensif sedangkan mendengar lebih pasif. Artinya menyimak bukan hanya sekedar mendengar tetapi lebih jauh lagi yakni mengenali lambang bunyi yang diujarkan oleh seseorang agar sesuai dengan maksud dari pengujar, dan tingkat yang lebih lanjut bisa memosisikan sikap atau menanggapi stimulus bahasa pengujar dengan respons yang baik.

Penyimak dapat dengan mudah mengenal simbol/lambang yang diujarkan oleh pengujar kemudian memberikan respons yang baik apabila penyimak tersebut sudah bayak mengenai simbol-simbol itu karena bayak diujarkan oleh komunitas di sekitarnya. Ini sejalan dengan pendapat Siegel (2011) listening used to receive little attention from scholars in the not so distant past. Bahwa keterampilan ini dipengaruhi oleh banyak morfem yang telah lampau diujarkan sesuai dengan pengalaman seseorang. Pendapat yang sejalan adalah listening was once regarded as a passive skill, or a tool to introduce grammar and vocabulary items (Field, 2008).semakin cepat seseorang penyimak dalam menerima dan menentukan respons yang tepat pada waktu yang sama menandakan orang tersebut telah menguasai keterampilan inidengan baik begitu pula sebaliknya. However, the simultaneity and spontaneity of listening makes it an inherently important, and at the same time, difficult skill to master. Listening usually takes place "in real time" which means that the listener must comprehend the aural input the moment it is uttered (Helgesen et al, 2003). Dengan demikian, diketahui betapa pentingnya keterampilan menyimak dengan mengasah keterampilan ini seseorang akan mampu memberikan tanggapan dengan baik, cepat, dan tepat saat peristiwa ujar yang terdiri atas 
pengujar dan penyimak ujaran yang berarti peristiwa ujar juga harus dihubungkan dengan peristiwa di lingkungan luar ujaran dan konteks ujaran.

\section{Tujuan Menyimak}

Mengasah keterampilan berbahasa sangat ditekankan karena bahasa bukan hanya tentang teori tetapi bahasa dalam kehidupan sosial berbentuk keterampilan nyata. Keterampilan nyata ini dapat berwujud keterampilan menyimak, membaca, menulis, dan berbicara. Pembelajaran bahasa memiliki fungsi sebagai sarana untuk meningkatkan kemampuan berpikir, mengungkapkan gagasan, menyampaikan informasi tentang suatu peristiwa, dan untuk memperluas wawasan (Saddhono, Waluyo, \& Raharjo, 2017). Keterampilan menyimak yang merupakan keterampilan reseptif cenderung pada penerimaan informasi melalui alat dengar manusia. Kiranya, penting untuk diasah karena keterampilan lain yang bersifat aktif yakni berbicara dan menulis sangat bergantung pada stimulus yang diterimanya sehingga dapat ditentukan respons terbaik untuk menanggapi stimulus tersebut.

Kebanyakan orang berpendapat bahwa kegiatan menyimak sama persis seperti mendengar. Mereka berpendapat bahwa keterampilan menyimak tidak penting atau tidak perlu di asah karena merupakan keterampilan pasif tetapi sebenarnya pendapatan ini sanggatlah keliru. Pasalnya keterampilan ini bukan hanya sebatas mendengar tetapi juga memahami berbagi konteks ujaran dan kemudian menentukan respons terbaik sebagai tanggapan sebelum membalas ujaran. Segala bentuk keterampilan pastilah memiliki tujuan yang hendak dicapai Menurut Iskandar (2008) tujuan menyimak dibedakan menjadi dua aspek, yaitu persepsi dan resepsi. Tujuan persepsi merupakan ciri kognitif dari proses mendengarkan yang didasarkan pada pemahaman pengetahuan tentang kaidah-kaidah kebahasaan. Resepsi merupakan pemahaman pesan atau penafsiran pesan yang dikehendaki oleh pembicara. Menurut Logan (Tarigan, 2008: 60), ada delapan tujuan orang menyimak sesuatu. Tujuan tersebut antara lain: a) menyimak untuk belajar, b) menyimak untuk menikmati keindahan audio, c) menyimak untuk mengevaluasi, d) menyimak untuk mengapresiasi, e) menyimak untuk mengkomunikasikan ide-ide, f) menyimak untuk membedakan bunyi-bunyi, g) menyimak untuk memecahkan masalah secara kreatif dan analisis, h) menyimak untuk meyakinkan dirinya. Dalam hal ini, melalui kegiatan menyimak mampu menemukan berbagai macam hal sesuai apa yang kita cari.

\section{Jenis-jenis Menyimak}


Seperti halnya keterampilan yang lain keterampilan menyimak memilik berbagi bentuk jenis dan tingkatan. Secara umum keterampilan menyimak ada dua jenis dan kedua bentuk menyimak ini merupakan tahapan di mana salah satunya memiliki tingkatan yang lebih tinggi tingkatan yang pertama lebih pada menyimak sebagai suatu keterampilan pasif untuk mengetahui maksud pengujar tanpa dibarengi dengan tanggapan yang baik, dan tingkatan kedua adalah tingkatan di mana penyimak memberikan respons yang baik dengan memperhatikan aspek dunia luar ataupun konteks ujaran pada saat peristiwa ujar. Menurut Tarigan (Nurhayani, 2017) jenis menyimak diklasifikasikah menjadi dua, yaitu: menyimak ekstensif, dan menyimak intensif. Adapun penjelasan setiap tingkatan jenis menyimak adalah sebagai berikut Menyimak ekstensif. Menyimak ekstensif adalah menyimak untuk memahami materi semakan hanya secara garis besar saja. Tarigan (2008) mengungkapkan bahwa menyimak ekstensif dapat dibedakan menjadi beberapa jenis, antara lain (1) menyimak sosial (2) menyimak pasif (3) menyimak estetis (4) menyimak sekunder (5) menyimak intensif.

Menyimak intensif adalah menyimak dengan penuh perhatian, ketekunan dan ketelitian sehingga penyimak memahami secara mendalam dan menguasai secara luas bahan menyimak. Berbeda dengan menyimak ekstensif yang lebih menekankan pada kesan subyektif yang berbeda pada setiap individu. Menyimak intensif lebih pada penyesuaian stimulus dengan pemberian respons terbaik. Menurut Nurbaya (2011) menyimak intensif dibagi menjadi (1) menyimak eksploratif (2) menyimak konservatif (3) menyimak komprehensif (4) menyimak kreatif (5) menyimak Interogatif (6) menyimak kritis. Menyimak dialog interaktif menempati strata keterampilan menyimak yang lebih tinggi dari sekedar menyimak ekstensif yang hanya kegiatan mendengarkan tanpa adanya tanggapan atau feed back dari siswa. Dalam menyimak intensif menyimak dialog interaktif termasuk ke dalam menyimak konservatif sehingga siswa selain mendengarkan dialog interaktif, ia juga menggarisbawahi informasi yang penting untuk kemudian diberi tanggapan terbaik sesuai isi dari rekaman dialog interaktif yang diperdengarkan di kelas.

\section{Menyimak Dialog Interaktif}

Melatih keterampilan menyimak siswa harus dilakukan karena kegiatan menyimak akan melatih siswa dalam membalas dan memberikan tanggapan terbaik. Latihan menyimak hendaknya tidak hanya bersifat mendengar tetapi juga memahami suatu bahan untuk menyimak. Dalam memilih suatu bahan untuk menyimak hendaknya pilihan tersebut dapat memenuhi tuntutan menyimak pada tahap ke dua atau tahap menyimak tinggi yakni menyimak ekstensif. Menyimak ekstensif yang baik untuk pembelajaran ialah menyimak konservatif 
dengan menyimak disertai tanggapan yang sesuai agar suatu ilmu pengetahuan dapat berkembang dengan pesat. Alternatif pilihan untuk meningkatkan kemampuan menyimak siswa adalah menyimak dialog interaktif. Kamus Besar Bahasa Indonesia (2008) dialog interaktif didefinisikan sebagai dialog yang dilakukan di televisi atau radio yang dapat melibatkan pemirsa dan pendengar melalui telepon. Menyimak dialog interaktif termasuk ke dalam jenis menyimak konservatif (concentrative listening), yaitu kegiatan menyimak untuk menelaah yang menitikberatkan pada susunan wacana tersebut secara global untuk memahami secara keseluruhan (Saddhono, 2019). Menyimak dialog interaktif perlu kecermatan dalam menyimak sehingga dapat memberi keputusan yang tepat saat memberi tanggapan.

Untuk melangkah lebih lanjut perlu adanya media yang sesuai dengan keterampilan menyimak, khususnya dialog interaktif. Di sini kiranya perlu diketahui pengertian media terlebih dahulu. Lowther dan Russel (2008) yang mengemukakan istilah media sebagai perantara yang mengantar informasi antara sumber dan penerima informasi. Dari definisi tersebut media menjadi alat perantara atau pengatar informasi atara suber dan informasi. Suber yang dimaksud dalam menyimak di sini adalah rekaman dialog interaktif yang disediakan sebagai bahan menyimak. Sedangkan penerima informasi adalah orang atau siswa yang mendapat tugas menyimak dialog interaktif yang termasuk menyimak konservatif.

\section{Penerapan Kegiatan Menyimak Dialog Interaktif dalam Pembelajaran}

Pembelajaran dengan media dialog interaktif dapat berjalan dengan lancar apabila dilaksanakan dengan media yang tepat. Pemilihan media yang tepat dapat mempengaruhi sukses tidaknya suatu pembelajaran. Pemilihan media hendaknya memperhatikan kondisi lingkungan dan latar belakang siswa. Selain itu media harus disusun dengan menarik agar dapat menarik simpati dan keaktifan siswa di dalamnya. Media tersebut dibuat menerik dan penuh kreativitas agar manusia lebih berminat untuk mengikuti media tersebut. Karena dengan hasil yang diinginkan dapat mengembangkan kreativitas seseorang dalam hidupnya (Saddhono, Waluyo, \& Raharjo, 2017)

Dalam kehidupan sehari-hari komunikasi yang bersifat audio sangat mendominasi kehidupan manusia. Penyimak berkonsentrasi untuk memperoleh dialog interaktif yang menarik perhatian yang diperlukannya Sriwidianingsih (2017). Kegiatan yang tercakup dalam menyimak dialog interaktif adalah (1) mengikuti petunjuk-petunjuk yang terdapat dalam pembicaraan; (2) mencari dan merasakan hubungan-hubungan seperti kelas, tempat, kualitas, waktu, urutan serta sebab akibat; (3) mendapatkan atau memperoleh butir-butir informasi 
tertentu; (4) memperoleh pemahaman dan pengertian yang mendalam; (5) merasakan serta menghayati ide-ide sang pembicara, sasaran maupun pengorganisasiannya; (6) memahami urutan ide-ide sang pembicara ; (6) mencari dan mencatat fakta-fakta penting ( arigan,1990).

Dalam kegiatan menyimak dialog interaktif terdapat sembilan tahap yang harus diperhatikan, Yaitu (1) mendengarkan bunyi atau kata tanpa reaksi hanya mengidentifikasi saja; (2) menyimak berselang/seling, menyimak dengan pikiran tidak terfokus; (3) setelah menyimak, hal-hal yang dibutuhkan saja; menyimak pasif, menyimak dengan sedikit atau tanpa respons sedikit pun; menyimak sempit, menyimak dengan menghilangkan bagian-bagian yang penting tapi menerima hal-hal yang dia setuju; (4) menyimak asosiatif, menyimak dengan menghubungkan hal-hal yang disimak dengan pengalaman; menyimak untuk mendapatkan ide-ide utamanya saja; (5) menyimak kritis, termasuk bertanya untuk mendapatkan informasi yang lebih mendetail mengenai suatu hal; (6) menyimak apresiatif atau kreatif, menyimak dengan respons secara mental dan emosional (Tarigan, 1990). 


\section{REFERENSI}

Ali, M. (1987). Guru dalam Proses Belajar Mengajar. Jakarta: Gunung Agung.

Arikunto, S. (1988). Prosedur Penelitian Suatu Pendekatan Praktik. Jakarta: Rineka Cipta.

Andersen, T. (1992). Relationship, Language and Pre-Understanding in the Reflecting Processes. Australian and New Zealand Journal of Family Therapy. https://doi.org/10.1002/j.1467-8438.1992.tb00896.x

Ariningsih. Sumarwati. Saddhono, K. (2016). Analisis Kesalahan Berbahasa Indonesia Siswa

Menengah Atas. Basastra Jurnal Penelitian Bahasa, Sastra Indonesia Dan Pengajarannya.

Depdikbud. (1992). GBPP Mata Pelajaran Bahasa dan Sastra Indonesia. Jakarta: Depdikbud.

Depdiknas. (2004). Kurikulum Pendidikan Dasar. Jakarta: Depdiknas.

Dunkel, P. (1986). Developing Listening Fluency in L2: Theoretical Principles and Pedagogical Considerations. The Modern Language Journal. https://doi.org/10.1111/j.1540-4781.1986.tb05250.x

Goldman-Eisler, F. (1972). Segmentation of input in simultaneous translation. Journal of Psycholinguistic Research. https://doi.org/10.1007/BF01068102

Hidayat, K. (1991). Perencanaan Pengajaran Bahasa Indonesia. Bandung: Bina Cipta.

Latifah, L., Saddhono, K., \& Wardhani, N. E. (2017). Language Variation Background In Social Context Of Community Utterances In Central Java- West Java, Majenang. Lingua Didaktika: Jurnal Bahasa Dan Pembelajaran Bahasa. https://doi.org/10.24036/ld.v11i1.7675

Mulyati, Y. (2017). Kosakata Siswa Sekolah Dasar Kelas Rendah (Kajian Jenis Kata, Bentuk Kata, Jenis Makna, Dan Medan Makna). Bahasa Dan Seni: Jurnal Bahasa, Sastra, Seni Dan Pengajarannya. https://doi.org/10.17977/um015v45i12017p099

Musfiroh, T., \& Endaswara, S. (2019). Pengembangan Media Pembelajaran Bahasa Berbasis Lingkungan Dan Teknologi. Diksi. https://doi.org/10.21831/diksi.v23i1.6621

Pandudinata, R., Sumarlam, S., \& Saddhono, K. (2018). Language Acquisition Of Children With Mental Disabilities In Pacitan. Humanus. https://doi.org/10.24036/humanus.v17i1.8542

Saddhono, K., \& Wijana, P. (2018). Wacana Khotbah Jumat di Surakarta: Suatu Kajian Linguistik. Jurnal Pendidikan Dan Kebudayaan. https://doi.org/10.24832/jpnk.v17i4.39

Saddhono, K., \& Rohmadi, M. (2014). A sociolinguistics study on the use of the Javanese language in the learning process in primary schools in Surakarta, Central Java, Indonesia. International Education Studies. https://doi.org/10.5539/ies.v7n6p25

Saddhono, K. (2019). Bentuk Dan Fungsi Kode Dalam Wacana Khotbah Jumat (Studi Kasus di Kota Surakarta). Adabiyyāt: Jurnal Bahasa Dan Sastra. https://doi.org/10.14421/ajbs. 2012.11104

Sibarani, R. (1992). Hakikat bahasa. Bandung: PT. Citra Aditya Bakti. 
Siegel, J. (2014). Exploring L2 listening instruction: Examinations of practice. ELT Journal. https://doi.org/10.1093/elt/cct058

Saddhono, K., \& Sulaksono, D\&. (2018). Indoglish as adaptation of english to Indonesian: Change of society in big cities of Indonesia. In IOP Conference Series: Earth and Environmental Science. https://doi.org/10.1088/1755-1315/126/1/012092

Sudjana, N. (1991). Dasar-Dasar Metode Belajar Mengajar. Bandung: Remaja Rosda Karya.

Sudjana, N. (2001). Metode dan Teknik Pembelajaran partisipasi. Bandung: Falah Production.

Suhendar, M.E. (1993). Efektivitas Metode Pengajaran Bahasa Indonesia. Bandung: CV Pionir Jaya.

Sumarlam (2017). Pemahaman dan kajian psikolinguistik. Solo: bukukatta.

Suparti, Nf. (2018). Analisis Kebutuhan Dalam Pengembangan Media Audio Bahasa Inggris Untuk Pembelajaran Menyimak Pada Siswa Smp N 5 Ngawen Gunungkidul. Jurnal Kwangsan. https://doi.org/10.31800/jkwangsan-jtp.v6n1.p13--26

Taguchi, N. (2005). Comprehending implied meaning in english as a foreign language. Modern Language Journal. https://doi.org/10.1111/j.1540-4781.2005.00329.x

Tampubolon. (1990). Kemampuan Membaca, Teknik Membaca Efektif dan Efisien. Bandung: Angkasa.

Tarigan, H.G. (1990). Menyimak sebagai Suatu Keterampilan Berbahasa. Bandung: Angkasa.

Waluyo, H. J., Saddhono, K., \& Raharjo, Y. M. (2017). Kajian Sosiologi Sastra Dan Pendidikan Karakter Dalam Novel Nun Pada Sebuah Cermin Karya Afifah Afra Serta Relevansinya Dengan Materi Ajar Di Sma. Jpi (Jurnal Pendidikan Indonesia). https://doi.org/10.23887/jpi-undiksha.v6i1.8627

Witkin, B. R. (2007). Listening Theory and Research: The State of the Art. International Listening Association. Journal. https://doi.org/10.1207/s1932586xij10401_3 